\title{
INTRODUKSI TANAMAN KORO MERAH DAN KORO KAPSUL SEBAGAI TANAMAN TUMPANGSARI PADA USAHATANI LAHAN KERING DI SUB-DAS SERANG DAERAH TANGKAPAN WADUK KEDUNG OMBO
}

\author{
Jaka Suyana, Dwi Priyo Ariyanto \\ Program Studi Ilmu Tanah Fakultas Pertanian, Universitas Sebelas Maret Surakarta \\ Email: jokosuyonouns@yahoo.com
}

\begin{abstract}
ABSTRAK
Permasalahan yang dihadapi petani lahan kering di Lereng Utara Gunung Merbabu adalah degradasi lahan akibat erosi dan pendapatan usahatani masih rendah. Kegiatan IbM Introduksi Tanaman Koro Merah (Kacang Merah) dan Koro Kapsul Pada Kelompok Tani Lahan Kering di Lereng Utara Gunung Merbabu ini merupakan kegiatan sosialisasi introduksi tanaman koro merah (kacang merah) dan koro kapsul ke dalam sistem usahatani yang telah ada (usahatani tembakau pada musim kemarau dan sayuran pada musim hujan). Tujuan introduksi tanaman koro merah dan koro kapsul adalah sebagai tanaman tumpangsari tembakau, dan juga kemungkinan pengembangannya sebagai tanaman substitusi/pengganti tembakau di kemudian hari. Mengingat sampai saat ini "tembakau" dianggap identik dengan "rokok" dan dipandang merugikan bagi kesehatan. Namun selama ini belum dipikirkan jenis tanaman yang dapat menggantikan tanaman tembakau tersebut. Tanaman koro merah dan koro kapsul disamping toleran terhadap kekeringan (dapat tumbuh baik pada musim kemarau), juga mempunyai nilai ekonomi cukup baik. Oleh karena itu akan diintroduksikan sebagai tanaman tumpangsari dengan tembakau dan monokultur. Kelompok Tani yang dipilih sebagai mitra yaitu Kelompok Tani Ngudi Makmur (Desa Ngargoloka, Kec. Ampel, Kab. Boyolali) dan Kelompok Tani Sumber Rejeki (Desa Candisari, Kec. Ampel, Kab. Boyolali). Khalayak sasaran meliputi seluruh anggota dari kelompok tani Ngudi Makmur yang jumlahnya 38 petani dan kelompok tani Sumber Rejeki yang jumlahnya 30 petani, termasuk juga aparat desa. Hasil dari kegiatan IbM ini menunjukan bahwa introduksi tanaman koro merah cukup berhasil dengan produksi berkisar 167-520 kg/ha, sistem tumpangsari yang dikembangkan petani meliputi : tembakau+koro merah, tembakau+koro merah+cabe, tembakau+koro merah+wortel, cabe+koro merah+bawang daun. Nilai gizi kandungan : (a) lemak pada biji koro kapsul $(2,28 \%)$ lebih tinggi dibandingkan biji koro merah $(1,56 \%)$; (b) protein biji koro kapsul $(23,39 \%)$ lebih tinggi dari biji koro merah $(14,26 \%)$; serta (c) karbohidrat pada biji koro merah $(69,42 \%)$ lebih tinggi dari biji koro kapsul $(56,57 \%)$. Target dari semua kegiatan ini (penyuluhan, pemberian benih, serta pendampingan di lapangan dan pemasaran hasil) diharapkan dapat menyadarkan petani untuk ikut berpartisipasi dalam introduksi tanaman koro merah dan koro kapsul pada sistem usahataninya.

Kata Kunci: lahan kering, tembakau, koro merah, koro kapsul
\end{abstract}

\section{PENDAHULUAN}

Permasalahan yang dihadapi petani lahan kering di Lereng Utara Gunung Merbabu yang merupakan wilayah DAS Serang, Daerah Tangkapan Waduk (DTW) Kedung Ombo adalah degradasi lahan akibat erosi dan pendapatan usahatani yang masih rendah. Hasil penelitian Suyana dan Muliawati (2012), ditunjukkan bahwa pada kawasan DTW Kedung Ombo telah terjadi degradasi lahan dengan tingkat degradasi berat seluas $1.046,14$ ha $(3,5 \%)$, degradasi sedang seluas $12.300,53$ ha $(41,3 \%)$, dan degradasi ringan seluas $16.471,79$ ha $(55,2 \%)$.

Dampak erosi yang terjadi pada lahan kering di Lereng Utara Gunung Merbabu ini akan menyebabkan penurunan produktivitas lahan, penurunan pendapatan petani, serta 
sedimentasi waduk. Banyak laporan menyebutkan bahwa tingkat sedimentasi yang terjadi pada Waduk Kedung Ombo saat ini semakin meningkat (Direktur Waduk, Sungai dan Danau, Departemen Pekerjaan Umum, 2008). Hasil penelitian Suyana dan Muliawati (2012), diperoleh bahwa sumber erosi penyebab sedimentasi Waduk Kedung Ombo paling dominan berasal dari erosi pada areal usahatani lahan kering di daerah hulu yang merupakan Lereng Utara Gunung Merbabu.

Keberhasilan usaha konservasi tanah pada sistem usahatani lahan kering di DTW Kedung Ombo merupakan bagian dari kegiatan pelestarian Waduk Kedung Ombo, dimana keberhasilannya lebih banyak tergantung pada peran serta dari subyek pelaksana kegiatan usahatani (petani) lahan kering yang berada di DTW Kedung Ombo. Untuk meningkatkan partisipasi petani dalam kegiatan konservasi tanah, sebaiknya Kelompok Tani lahan kering di DTW Kedung Ombo dapat bekerjasama dengan Perguruan Tinggi dan Petugas Penyuluhan Lapangan (PPL) dinas terkait, agar pengetahuan petani tentang teknik-teknik konservasi dapat ditingkatkan sehingga lebih mampu menjaga dan melestarikan lahan usahatani mereka.

Sistem usahatani lahan kering di wilayah lereng utara Gunung Merbabu memiliki kondisi agroklimat/agroekologi yang mirip dengan daerah asal tanaman koro merah dan koro kapsul di lereng Gunung Sumbing dan Gunung Sindoro Kabupaten Temanggung. Berdasarkan pemikiran tersebut, maka akan dilakukan kegiatan $\mathrm{I}_{\mathrm{b}} \mathrm{M}$ Introduksi Tanaman Koro Merah (Kacang Merah) dan Koro Kapsul (Kacang Senerek) Pada Usahatani Lahan Kering Terdegradasi di Lereng Utara Gunung Merbabu DTW Kedung Ombo, dengan tujuan untuk : (a) mengembangkan kelompok tani tersebut agar dapat melakukan tindakan konservasi tanah secara vegetatif dan dapat meningkatkan pendapatan usahataninya; (b) membantu menciptakan kerjasama, ketentraman dan kenyamanan dalam kehidupan bertani dan bermasyarakat; (c) meningkatkan keterampilan berpikir dalam mengembangkan sistem pola tanam yaitu dengan introduksi tanaman koro merah dan koro kapsul sebagai tanaman tumpangsari, dan juga kemungkinan pengembangannya sebagai tanaman substitusi/pengganti tanaman tembakau di musim kemarau. Tanaman tembakau disamping mempunyai banyak manfaat juga dapat memberikan dampak negatif bagi kesehatan. Selama ini "tembakau" selalu diidentikan dengan "rokok" yang merugikan kesehatan.

Oleh karena itu, pada kegiatan IbM ini tanaman koro merah dan koro kapsul akan diintroduksikan sebagai tanaman tumpangsari dengan tanaman tembakau dan sebagai tanaman monokultur. Bertujuan untuk meningkatkan pendapatan petani dan juga kemungkinan pengembangannya sebagai tanaman substitusi/pengganti tanaman tembakau. Karena disamping toleran kekeringan tanaman koro merah dan koro kapsul juga mempunyai prospek pasar dan nilai ekonomi yang cukup tinggi (harga biji koro merah dan koro kapsul berkisar Rp. 11.000 - 17.000,- per kg).

Mengingat selama ini pembinaan petani lahan kering di wilayah hulu DAS masih sangat lemah, sehingga untuk adopsi teknologi tersebut perlu dilakukan kegiatan $\mathrm{I}_{\mathrm{b}} \mathrm{M}$ ini. Mitra yang dipilih pada kegiatan $\mathrm{I}_{\mathrm{b}} \mathrm{M}$ ini, yaitu : Kelompok Tani Ngudi Makmur (di Desa Ngargoloka, Kecamatan Ampel, Kabupaten Boyolali) dan Kelompok Tani Sumber Rejeki (di Desa Candisari, Kecamatan Ampel, Kabupaten Boyolali).

\section{METODE}

Metode yang digunakan adalah metode riset aksi atau kaji tindak, meliputi : kegiatan penyuluhan, FGD (Fokus Grup Diskusi), dan pendampingan. 
Metode kegiatan meliputi :

1. Pelaksanaan kegiatan dilakukan dengan cara bersama-sama dengan mitra/kelompok tani dan perangkat desa untuk mengidentifikasi permasalahan, kebutuhan serta melakukan perencanaan sampai pelaksanaan kegiatan serta evaluasi.

2. Sosialisasi tentang introduksi tanaman koro merah dalam pengembangan teknologi konservasi "hedgerows" pada usahatani lahan kering.

3. Pendampingan di lapang sampai pada pemasaran hasil tanaman koro merah.

Partisipasi mitra dalam pelaksanakan program IbM ini meliputi: penyediaan lahan dan sumberdaya manusia sebagai subyek untuk dilatih dan didampingi berbagai program ini.

\section{HASIL DAN PEMBAHASAN}

Hasil yang dicapai dalam kegiatan pengabdian ini adalah introduksi tanaman kacang merah (Gambar 1) sebagai tanaman tumpangsari dengan tembakau cukup berhasil, dengan produksi sekitar 167-520 $\mathrm{kg} / \mathrm{ha}$ diatas produksi di daerah Kabupaten Temanggung 267-370 kg/ha (Suyana, 2012).

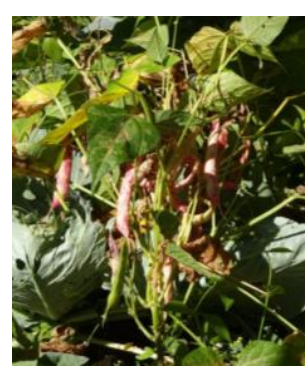

Tanaman koro merah
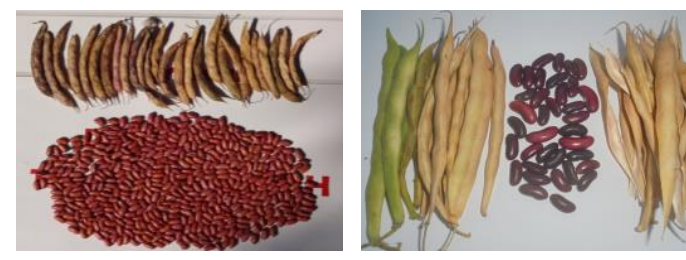

Polong dan biji koro merah (kiri) polong dan biji koro kapsul

Gambar 1. Tanaman koro merah dan koro kapsul
Produksi koro merah tertinggi pada pola tumpangsari (koro merah + tembakau), diikuti tumpangsari (koro merah + tembakau + kubis), tumpangsari (koro merah + tembakau + wortel), dan tumpangsari (koro merah + tembakau + cabe). Sebagaimana ditunjukkan pada Gambar 2 dan Tabel 1.

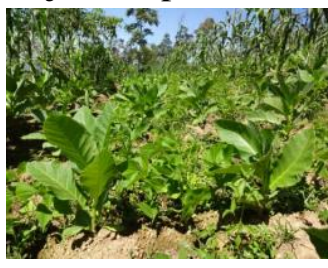

koro merah + tembakau

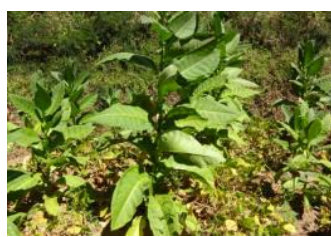

koro merah + tembakau + kubis koro merah + tembakau + wortel

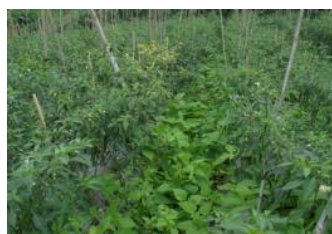

koro merah + tembakau + cabe

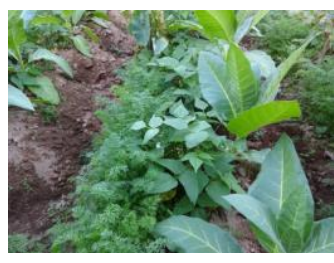

Gambar 2. Jenis tumpangsai

Tabel 1. Produksi koro merah berdasarkan jenis tumpangsari

\begin{tabular}{lc}
\hline \multicolumn{1}{c}{ Jenis Tumpangsari } & $\begin{array}{c}\text { Produksi } \\
(\mathrm{kg} / \mathrm{ha})\end{array}$ \\
\hline Koro merah (Km) & $260-520$ \\
tembakau & \\
$\mathrm{Km}+$ tembakau + cabe & $167-334$ \\
$\mathrm{Km}+$ tembakau + kubis & $285-338$ \\
$\mathrm{Km}+$ tembakau + wortel & $249-336$ \\
\hline
\end{tabular}

Hasil biji koro merah mempunyai prospek pasar cukup baik selama ini dimanfaatkan untuk sayur sop, kumbu, selae, es cream Ogura, dan lainya karena mempunyai warna alami merah yang menarik konsumen. Berdasarkan hasil analisis laboratorium nilai kandungan : (a) lemak pada biji koro kapsul $(2,28 \%)$ lebih tinggi dibandingkan biji koro merah (1,56\%); (b) protein biji koro kapsul $(23,39 \%)$ lebih tinggi dari biji koro merah $(14,26 \%)$; serta (c) karbohidrat pada biji koro merah $(69,42 \%)$ lebih tinggi dari biji koro kapsul $(56,57 \%)$. 


\section{KESIMPULAN}

1. Introduksi tanaman koro merah sebagai tanaman tumpangsari (koro merah + tembakau) cukup berhasil, dengan produksi sekitar $167-520 \mathrm{~kg} / \mathrm{ha}$.

2. Sistem tumpangsari tanaman koro merah yang dikembangkan petani meliputi : tembakau+koro merah, tembakau+koro merah+cabe, tembakau+koro merah+wortel, cabe+koro merah+bawang daun.

3. Nilai gizi kandungan : (a) lemak pada biji koro kapsul (2,28\%) lebih tinggi dibandingkan biji koro merah $(1,56 \%)$; (b) protein biji koro kapsul $(23,39 \%)$ lebih tinggi dari biji koro merah $(14,26 \%)$; serta (c) karbohidrat pada biji koro merah $(69,42 \%)$ lebih tinggi dari biji koro kapsul $(56,57 \%)$.

\section{SARAN}

Menyadarkan petani untuk melakukan introduksi tanaman koro merah dan koro kapsul (ditumpangsarikan tembakau), diperlukan pendampingan yang baik serta berkelanjutan.

\section{DAFTAR PUSTAKA}

Direktur Waduk, Sungai dan Danau, Departemen Pekerjaan Umum. 2008. Pengelolaan Air Wduk Terlantar, Waduk Mengancam. http://64.203.71.11/kompascetak/2008/01/07/ilpeng/4143880.htm.

Suyana. 2003. Penerapan Teknologi Konservasi Hedgerows Untuk Menciptakan Sistem Usahatani Lahan Kering Berkelanjutan. Pengantar Falsafah Sains (PPS702), Program Pascasarjana/S3, IPB. Posted 25 October, 2003.

Suyana, J. dan E. S. Muliawati. 2012. Perencanaan Sistem Petanian Konservasi Pada Sub-DAS Serang Daerah Tangkapan Waduk Kedung Ombo. Laporan Hasil Penelitian Hibah Bersaing Dengan Perguruan Tinggi Tinggi. Universitas Sebelas Maret, Surakarta. 